\title{
A Gift of Grapes: \\ What Biography Reveals of the Uniquely Religiously-based Friendship between P.Q. Vundla and Nico Ferreira
}

\author{
Garth Mason
}

\section{Abstract}

This article examines the forgotten historical narrative in the social history of South Africa of the unique friendship between P.Q. Vundla and Nico Ferreira. The two men stood at diametrical positions on the South African political stage - P.Q. Vundla, an ANC activist and Nico Ferreira, an Afrikaner working for the Department of Native Affairs. Their friendship was forged through their membership to the Moral Re-armament Movement, a Christian inspired international peace initiative in the mid-twentieth century. The article focuses on the beginnings of their friendship during the time of the Sophiatown forced removals in 1955. The study is a close reading of the biographies of their lives penned by the two men's wives Nchibadi Betty Kathleen Mashaba (Kathleen Vundla) - P.Q.: The story of Philip Vundla of South Africa (1973) and the Nico Ferreira's biography - In case anyone asks (2006) written by Loël Ferreira. Kathleen Vundla and Loël Ferreira's biographies provide important information about P.Q. Vundla's and Nico Ferreira's spirituality in the context of their community work and friendship. Both biographies offer privileged information about the inner life of the two men that assists in understanding their motivations behind their political work. First, they are read as mediated renderings of their respective husbands' lives and therefore the data offered is filtered through memory and interpretation. Second, the biographies have a unique status as privileged windows into two forgotten lives. The friendship between P.Q. Vundla and Nico Ferreira is an untold story of racial conciliation, religiously inspired, within a politically contested space. A nuanced analysis is required to provide an adequate explanation for the friendship between the two 
men. This article makes such an attempt by establishing an ethical lens via Levinas's religio-ethical writings on alterity and transcendence through which to view their friendship.

Keywords: P.Q. Vundla, Nico Ferreira, Moral Re-armament Movement, Biography, Sophiatown

\section{Introduction}

P.Q. Vundla and Nico Ferreira are both uniquely complex figures in South African Apartheid history and their friendship affords us, as witnesses to their lives, a multifaceted understanding of selves and relationality in early Apartheid history. Their involvement with the Moral Re-armament Movement (MRA) (Spoerri 1976: 121) placed them in the ambiguous and marginalised position of being oppositional to colonial and Apartheid power, while also embracing the colonial religious narratives in the MRA philosophy. This article examines the conditions of possibility created by the MRA movement, which permitted the two men to become friends. The biographies of Vundla and Ferreira provide a conduit for the two men's marginalised voices and help to explain their life trajectories, which might otherwise be misunderstood and help us to understand the conditions of possibility for their friendship. In this regard I argue that biographies, such as the two examined in this article, allow for the development of integrative complexity (Pinker 2011: 805) in the writing, particularly when read in tandem. The intersecting narratives about a shared historical context in the two texts foster a dialectical view of self and other regarding their friendship. Subjective accounts of history, Caine (2010: 16, 18) and Luz Fuentes-Vàsquez (2013: 167) observe, are governed by specific economic and social contexts. However, these two biographies are micro-histories as opposed to biographical histories of great people (2010: 23), and they combine the domestic with the public (Caine 2010: 24 and Barbour 2004: 9). I find P.Q. Vundla and Nico Ferreira to be elusive threads in the political tapestry of South Africa, particularly in the middle decades of the twentieth century in Johannesburg in that they do not fit into the grand narrative of Apartheid history. Their lives are not the macro-histories of activists resisting proletarianization or wage employment, or of white colonial oppression. Rather their stories, as represented in their respective biographies, 


\section{Garth Mason}

require a different framework derived from integrated relationships with others and belief in the dialectical interconnectedness of 'self and other' that, in Levinas' analysis, becomes the foundation for ethical action. The elements that contributed to their friendship, including spirituality and empathy, I argue, contributed to the profound and distinctive lives they both led. In this respect the function of religious 'space' is considered as an architect of inner spiritual environment, which is externalized from the spiritual community into the wider social community through a process of recognising the 'highest qualities' in the other, reminiscent of Levinas's thought. Levinas writes,

[T] he proximity of the other showing me his or her face, in society with me, and the implications of that encounter overturn the logical and the ontological play of the same and the other, transforming it into ethics (Levinas 1999: 76).

I argue that Vundla's and Ferreira's identities, as revealed in the two biographies, were inclusive of saintly otherness ('alterity' in Levinas's terms, 1999: 171). As Peperzilk explains in his introduction to Levinas's thought: 'My home, my food and beverage, my labour, and all my possessions of the earth that I enjoy receive their definitive meaning by being put into the service of another who, by her unchosen 'height', makes me responsible' (1993:24). Vundla and Ferreira's motivation to reach out across the divides in society was informed by the religious thought in MRA philosophy. The MRA influence is crucial to their complex identities in that it formed the basis of their political discourses, founded on a Christian narrative of the Cross and the Holy Spirit (Howard 1962: 20). This was the basis of daily spiritual practice in the movement and allowed a deeper spiritual attitude to the other (which Levinas philosophised about (Peperzilk 1993: 58)) to emerge. I explore the notion that religious identity is a particularly deep aspect of identity that, to some degree, transcends social and political forms of identity; in the case of Ferreira's and Vundla's philosophy of alterity and transcendence, religious identity is corroborated. It offers a 'higher set of principles' that enables moral choices that are not specific to political or social constructs. A more complexly constructed self is enabled to emerge, which imagines the highest qualities of saintliness in the other. These moral choices are imbued with the spiritual values of forgiveness and love. 
The MRA was a Pentecostal-inspired world peace movement in the twentieth century. Although it was not a Christian movement it was inspired by Pentecostal preachers in Philadelphia in the early twentieth century which distilled Jesus's teachings into basic principles of honesty, unselfishness, purity, and love. Although not explicitly Christian, the MRA movement saw the Holy Spirit as its sole authority (Mowat 1955: xvi). Nico and P.Q. were members of the MRA movement until the early 1970s. The Movement's tendency for utopian socialist - humanitarian relations between people and communities (Marcel 1960: 4) gave Nico and P.Q. a philosophical and activist trajectory.

This paper accesses the lives of P.Q. and Nico via their wives' biographies. Kathleen Vundla's and Loël Ferreira's biographies of their respective husbands are mediated renderings of their husbands' lives and therefore their narratives are filtered through memory and interpretation. But, as P.Q. Vundla's and Nico Ferreira's wives, they share the marital space, together with social context, which makes their biographies unique windows into their private lives as well as the social and political dimensions of their experience. These two biographies provide 'intimate' narrations of the two men's lives that lean towards affective accounts of their lives. The affective covers emotional responses in the two texts, such as fear, hope, love and moral desire to bring justice to disempowered communities. I will show how these affective records of the two men's lives opens a window to the inner spiritual dimensions of their lives. These emotions led Nico and P.Q. to seek out community and friendship relations in their external environments as imagined spiritual and emotional environments imbued with values, relations and beliefs. These external environments offer a sense of belonging to human communities beyond political, class and race boundaries reinforced by beliefs and values that reach towards spiritual coordinates.

The biographies of Loël Ferreira and Kathleen Vundla afford us the lens to view the private and public lives of the two men. I argue that these two biographies are distinctive in terms of what Lois Banner refers to as the 'intermixing of genres' between biography and autobiography which I will show allows for a complex relation between objective and subjective accounts of the two men (2016: 101). Where normally biography is seen to be the venue of research and autobiography as personal disclosure, Banner concedes that there are definite similarities between the two genres: the element of characterization, the imposition of significance and the interpretation of events 


\section{Garth Mason}

(2016; 102). But also, very significantly for this article, Banner contends that the role of identification between the biographer and her subject cannot be ignored. This point is germane because the two biographers being studied are spouses of the biographical subjects (102: 2016). Banner terms this type of biography 'biographical autobiography' (2016: 104). In this genre, the biographer draws personal memory together with family and friends and incorporates photographs and memorabilia. Banner avers that such content, which is very close to the subject of the text, can offer specific historical representations, which conventional scholarly research may not perceive. But, conversely, biographies can also conceal material. This article will endeavour to uncover what has been concealed by extensive contextual research and cross-referencing between the two biographies.

I agree with Banner when she writes that the biographer is an historian who presents a kaleidoscopic personality 'as a tapestry, a weaving together of many threads and colours (sic) in changing but also continuing patterns' (2016: 105). This representation of personality is complex and nuanced and depicts a person in their fluidity and dynamism with a multiplicity of interwoven narratives. This complexity is enriched when the two biographies are read as complementary texts relating stories of the same historical events. What emerges from my approach is a complex biographical reading that combines affective elements with the socio-historical recording of the two men's lives (2016: 106).

Much of this article is concerned with the concept of movement, both psychological and physical, in the lives of Vundla, Ferreira and those Sophiatown residents whose lives were altered drastically by forced removals. For Vundla and Ferreira, their movements across external and internal landscapes entailed perceptual changes, bringing about new choices, beliefs, judgements and values due to embodied temporal and spatial determinants. Ultimately, these shifts were due to the draconian destruction of lived place by the Apartheid government. Kathleen and Loël's biographical autobiographies reveal these internal and external shifts in perspective. This article asks what can be learnt from the two wives' autobiographical biographies that would explain their husbands' responses to each other during the events of the Sophiatown removals and the consequences for the rest of their lives? I am interested in determining the role biographical autobiography can play in understanding research subjects' actions. The texts provide insights into the two men's increasingly complex articulations of self-construction. When read 
together, the two biographical autobiographies provide the reader with insights into the spiritual grounding of their subjects' work and friendship.

It is necessary to be sensitive to interpretations Kathleen and Loël (and their subjective contexts) could impose on the two men's lives. Aspects of gender, spousal relationships, and power in reading the two biographical autobiographies are therefore important considerations.

\section{Key Concepts}

It will be useful to devote a short section to defining some key concepts in this article to assist in better understanding of the research argument. Six concepts need explaining; spirituality, self, other, history, race, integrative complexity and relationality. Spirituality is understood in this article as a non-material awareness. Whereas materiality focuses on material conditions, spirituality focuses on awareness of non-material aspects of life, including emotional relationships, personal interiority, non-egoic connectedness with others and divinity. Self is understood as an experience of identity that is constructed from experiences. Otherness is understood as that which is not constructed from one's own experiences. Relationality is a sense of coming to an understanding of views other than one's own. Integrative complexity is understood as a mode of self-expression that incorporates complex and contradictory narratives displaying a self's awareness of the complex interweaving narratives that comprise social reality. History is understood to be separated between macro and micro histories. In broad terms the grand narratives of history tend to dominate social memory. Micro histories as encapsulated in biography and autobiography provide micro histories that can conflict with grand narrative histories, but can also add depth and richness to social memory. Race is comprehended in a South African Apartheid context, where inequality and power was inscribed into the social fabric in terms of whiteness and nonwhiteness.

\section{Theoretical Framework}

This article applies Levinas's theory of ethics to the friendship between P.Q. Vundla and Nico Ferreira. I utilize Levinas's ideas on self and other to give a hermeneutical framework for examining the spiritual foundations of the 


\section{Garth Mason}

friendship. Levinas argues that ethics emerges out of the relation between self and the other, and more specifically, the transcending of the 'I' into the space of the 'other' - in its complete otherness or alterity. Levinas writes of 'the conversion of the for-itself into a responsibility for-the-other' (1999: 35). I argue that both Vundla and Ferreira show signs in their thinking of integrative ethics, resonant with Levinas' ethics in utterances captured in their wives' biographies as they came to an understanding of others across racial lines. Their integrative ethics stand in contrast to the political organizations' discourses to which they belonged, namely Ferreira's National Party and Vundla's African National Congress. According to Levinas, ethics should not be rooted in any singular ideology. Rather, Levinas (1999: 35) refers to the,

heteronomy of ethical obedience, which, in the guise of inspiration, is not the unfolding of a vis a tergo [a force from behind]: it comes from in front (de face) [of the face]: submission to the order issued (signife) [bearing] in the face of the other man which is not approached as a theme.

The foundation of ethical inspiration that Levinas describes helps to explain the underlying fabric that inspired Vundla and Ferreira to become friends based on shared ethical values of the MRA movement in spiritual elevation of the 'naked' face-to-face encounter (Levinas 1999: 92). Such an ethical inspiration requires movement (both physical and psychological) from personal secure space to the space inhabited by the other.

Reading Levinas's ethics into the two biographical autobiographies provides a useful hermeneutic tool by which the integrative ethics of the two men can be explored. More especially, in reading the biographical autobiographies in tandem, a picture of shared integrative ethics emerges. Both P.Q. Vundla and Nico Ferreira challenged political mainstream opinion, on the political left and the right. Their commitment to community interests and bringing disparate communities into proximity is revealed in a joint reading of the texts. I aver that their religio-political approach is akin to Levinas's description of Buber's 'utopian Socialism' as emerging from 'the failure of Socialism as a state policy [which] initiated the [utopian] socialism of civil society' (Levinas 1999: 112).

Both P.Q.'s and Nico's lives portray dedication to improving the lives of disempowered communities through promoting civil society. The mutual 
receptivity between the two texts brings the two lives into intimate proximity. Levinas writes of such proximity as the nearness of people to each other, which transcends notions of abstract rights such as inalienable, historical rights or principles (Levinas 1999: 88). Levinas advocates a lived ethics based on the co-presence of people, and out of that proximity a new spiritualty emerges community driven socialism founded on the elevation of the 'other' into a saintly being. The reading of the two biographies highlights the proximity of these two men to each other and to their wives. Each text depicts a life lived on the political margins.

It is in narrating lives that they take on social and political significance, or what Leonor Arfuch refers to as 'circuit of communication' (2016: 273). This is perhaps especially true for biographical autobiography, particularly in the present case when two narratives tell intersecting narratives from a wife's perspective. When the life is narrated by a close associate, such as a wife, there is a heightened sense of inter-subjectivity and relationality in the writing. The viewpoint proffered by the biographer in a sense participates in the viewpoint of the protagonist and the narrative becomes an ethical defence of life choices made. Memories, normally reside solely via individual recall (Arfuch 2016: 274). But in biographical autobiographies the complexities of identification give expression to nuance and relationality due to the proximity of the narrator to the life. The biographical autobiographer endeavours to answer the question, how should the loved one be remembered? The biographical autobiography wrestles with the private, the ethical, the aesthetic, and the political. These discrete factors are held in the author's perspective, according to Arfuch. In this sense the biographical autobiographer enunciates a memory of self that is constituted by fragments of these four elements. She decides on the limits of what is private and what can be divulged; in doing so, she sets up, from her intimate viewpoint, the narrative boundaries between private and public (2016: 274). Paradoxically, however, in setting these boundaries the auto/biographer, allows complex and nuanced memories to be shared by the public. These nuanced memories are very important when reading the biographical autobiographies. When they are read together a more intimate picture of the friendship emerges than when reading either one of the texts on their own. I use the term 'integrative complexity' to describe the picture constituted by reading the two texts in tandem. Integrative complexity points to the layered textuality of merging the personal with the social. The complexity of represented selves in biographical autobiography is made even more revealing 
when the two biographies are read as intersecting lives. Levinas's ethics of 'for-the-other' is clearly shown in these two intersecting texts.

This article will therefore examine the relational component of otherness with the self, particularly, in its development in P.Q. Vundla and Nico Ferreira. Initially the role of otherness will be explored in terms of the authors of the two texts, Loël Ferreira and Kathleen Vundla, as women and the influence of colonialism on their voices. The focus will then shift to Ferreira's and Vundla's childhoods and youthful years to inspect how the sense of relationality began developing in both men with a sense of communal ethics. The article will then investigate how their friendship developed across political and racial borders with an emerging understanding of relationality that incorporated otherness. The ethics that accompanied this other-based relationality had a common spirituality provided by the Christian-informed MRA movement. The article will then analyse how their friendship developed against the historical backdrop of the Sophiatown forced removals and iniquitous unfoldment of the broader Apartheid policy.

\section{Methodology}

A close comparative reading of the two biographies of Nchibadi Betty Kathleen Mashaba, P.Q.: The story of Philip Vundla of South Africa (1973) and of Loël Ferreira's, In case anyone asks (2006) is undertaken. Comparison is a useful research technique in this study for two reasons; first, due to their close friendship many events are recorded in both texts from varying perspectives. Second, P.Q.'s and Nico's lives were lived in parallel but across the racial divide. The comparative reading draws attention to their contrasting life experiences.

\section{Kathleen Vundla's Biographical Autobiography and the Difficulty of the Other as White Colonial Voice}

In terms of Levinas's ethics of the other it is important to be aware of the problem of the colonial voice in biographies written by disempowered people but published by 'white publishers' for white readers. P.Q.: the story of Philip Vundla of South Africa by Kathleen Vundla was published in 1973 by the Moral Re-Armament Press in the Cape Town, South Africa. It falls into the 
contested category of biographical autobiographies written by colonised peoples but edited or assisted by white colonial writers. This issue is particularly relevant to autobiographies by colonised writers in the twentieth century. During the $21^{\text {st }}$ century there has been growing sensitivity to the ethical problems of ensuring that indigenous voices are palatable to a western audience. Even with this sensitivity, there is still an element of white colonial 're-authoring' of some recent texts, although this is phrased as 'assisted by' or 'worked together' (2016: 172).

Kathleen Vundla's auto/biography was a somewhat enlightened text for its time: in the Author's note Vundla writes that she is 'very grateful to Barbara Burns who helped me with this book' (1973: 9). It is not clear from the Author's note what assistance Burns rendered, whether editing or more basic manuscript development assistance. Kathleen makes the further admission in the Author's note that 'much of the book is taken from notes [left by (P.Q.) and events as he saw them and interpreted them at the time' (1973: 9). She therefore wants to convey that, while she is the author, she is a conduit for her husband's voice in the text.

It is, however, significant that P.Q. and Kathleen were committed members of the Moral Re-Armament Movement (MRA). Taken together with the fact that the book is published by the MRA, this suggests that Kathleen is not only dedicated to communicating her husband's impressions and memories, but also the religious philosophy and international agenda of the MRA.

\section{The Complexity of 'otherness' in a Female Voice Narrating a Male Life}

Women's biographies of their husbands provide complex hybrid combinations of male and female voices. In Kathleen's biography the male voice is dominant, but in Loël's biography, her voice is prominent. It may be stereotyping to argue that women's autobiography would be more personal and emotional, more focused on the home, in their construction of self. This is, however, what Magdalena Maiz Peña and Luis H. Peña suggest in their chapter, 'Between the lines: constructing the political self' in the Routledge auto/biography studies reader (2016: 79). But, as a point of debate, this view helps in situating the auto/biographies of Vundla and Ferreira. Kathleen's 


\section{Garth Mason}

voice is not very distinctive in her biography. It is a chronological collection of P.Q.'s notes strung together in narrative form. She does not offer personal interpretations of his notes and she does not feature as a protagonist in the narrative. Her biography is strictly on the biographical side of biographical autobiographical writing, but she offers a domestic lens into their lives, whereas Loël belongs on the autobiographical side of the spectrum, but does not allow a domestic voice to emerge. Kathleen, for example, observes that P.Q.'s relations with her and their children become gentler after he joined the MRA movement. He was no longer stern towards the children and he ceased 'treating her more like a servant than his wife' (1973: 45). Loël's biography is primarily a celebration of her life together with Nico and her part in their joint life. It does not intend to be a biography of Nico. In the Explanatory note from Nico and Loel Ferreira at the beginning of the book Loël writes,

In the end we found we couldn't actually both author the book and, as the bulk of the work was getting all the info (sic) onto the computer, the final author is Loel.

But it is the story of what we did with our lives, separately and together, in case anyone forgot to ask at the time (2006: ii).

\section{Childhoods Compared}

As constructions of self, both biographies lean toward history to provide empathic interpretations of the men's lives. However, they do not set out to give background to a social/political analysis of P.Q.'s and Nico's lives. Rather, both biographies begin by describing childhood to sketch a humanitarian perspective of early life that reveals roots for people who were able to discover compassion within the brutality of the forced removal of Sophiatown.

Kathleen's recounting of P.Q.'s childhood gives a brief outline of the context of his childhood in Healdtown, gleaned from P.Q.'s notes and memories shared with her. P.Q., she writes, was born into peasant conditions, into a large family of eight children. She opens by outlining P.Q.'s political context. His parents were liberal; they were one of the first to sign up on the Cape voters' roll, and were supporters of the Botha government. She writes how P.Q.'s politics shifted to radical anti-colonialist when he was excluded on 
racial and political grounds from a bursary to attend Lovedale High School (Vundla 1973: 11-16). This exclusion from economic support was the tipping point for the radicalisation of his politics after years of being subjected to racial discrimination in the classroom at the Healdtown mission school. Kathleen writes that after this, P.Q. developed a deep hatred for whites, which was encapsulated in his oft-asserted exclamation 'the only good white is a dead white!' (Vundla 1973:16).

Ferreira grew up on a farm in the Orange Free State Province. Loël Ferreira writes in In case anyone asks (2006) that Nico was born on 28 September 1929. He grew up on the family farm in the Orange Free State. The family had Portuguese settler heritage but had assimilated into Afrikaans culture through marriage into a French Huguenot family. The family was poor, still carrying the scars of the South African War and the cruelty of the women's concentration camps, where Nico's grandmother and her children had suffered (Ferreira n.d.: 1). Memories of his grandmother internment and death in South African War would have lingered.

The two biographical autobiographies strive to offer personal narrative of the two men's lives. But they are also composite representations of P.Q.'s and Nico's lives, including personal and public histories. They are, as Maize Peña and Peña describe, 'biographical autobiography,' or complex working out of the relationship between personal and political selves (2016: 77). They are story and history simultaneously (2016: 78). But the history written in this context is one in which private utterance enters public space but also contests the dominant public narrative.

The intention behind writing the two auto/biographies differs. Kathleen's intention is to ensure the legacy of P.Q.'s work as an activist and community builder. Loël captures her intention in the title of her book, 'In case anyone asks'. She seems to be writing the book for private interest, family and friends (2006: ii). She is not anticipating a large readership. There is a despondency of a silenced voice in the writing.

The two biographical autobiographies do not record lives on the grand scale. There is neither the heroic nor the epic in the recounting of the narratives. There is, though, a degree of quiet heroism in the two men's lives of integrity inspired by a higher moral principle against the prevailing political forces and directed towards social development. Both men are not influenced by public opinion. They are modest voices of dissatisfaction with political parties imposing their will on communities. In this article I focus on how the two 


\section{Garth Mason}

biographies represent the two men's complex integrations of private voices (expressing modes of subjectivity) negotiating their relationships with the collective consciousness. But more specifically, I focus on a mode of relationality that is akin to Levinas's writings on transcendence and alterity, where 'the ethical' involves the subject engaging asymmetrically with the other - putting the needs of the other before the self (Levinas 1969: 215; Levinas 1999: 33).

\section{The Roots of Relationally-based Ethics in P.Q.'s Narrative}

P.Q. shows signs of relationally-based ethics in his youth and early adulthood in concern for suffering in his community, both where he lived and where he worked. Kathleen begins her construction of P.Q.'s life narrative by setting up a tension between liberal and radical values that existed in Healdtown, his childhood town. Kathleen's tone is almost one of objective reportage as she describes the devastating poverty and discrimination that was P.Q.'s childhood experience. She merely sets the scene of P.Q.'s early personality formation. She describes P.Q.'s growing antipathy to whites in dispassionate analytical terms when she writes, 'it seemed logical to blame the whites for the poverty of his people' (Vundla 1973: 16). This may be because she does not want the text read as politically angry and radical; or perhaps because her own political position is liberal and therefore would emphasise the value of personal struggle. I read profound respect in Kathleen's account of her husband's inner life and thought; she does not want to impose her interpretation on his inner being. Kathleen quotes directly from P.Q.'s notes instead of giving her own interpretation. In one instance she quotes P.Q.'s notes when he first arrived on the Witwatersrand as a contract miner:

I was opposed to the treatment of African workers by the mining company employers, both on the grounds of the low wages they were getting and because black miners get less compensation for injury than white miners. I regard the whole African migrant labour system as immoral (Vundla 1973: 17).

She does, nevertheless, offer the reader a glimpse into the roots of P.Q.'s anger and violent nature, which she endured in the home along with their children (Vundla 1973: 45). 
As P.Q. matured as an activist he was able to channel his anger into helping 'his people' overcome the poverty caused by colonialism. However, Kathleen narrates that before P.Q. became a community activist, he was politicised as a witness in the Lansdowne Commission in 1943 on working conditions of black miners. Mine officials threatened him with losing his job if he testified. This led him to become a Unionist as secretary for the South African Mine Workers Union on the Witwatersrand after testifying at the Commission (Vundla 1973: 28). He, together with the SACP leader J.B. Marx, was one of the organisers of the miners' strike of 1946. Unfortunately, the strike was quelled due to new legislation prohibiting group meeting or assembling (http://www.sacp.org.za/main.php?ID=2304; accessed 2 June 2017).

Kathleen observes that P.Q. was deeply involved in ANC in the period between 1940-1950. He was involved with salary increase protests for teachers in the centre of the Johannesburg CBD (Vundla 1973: 27). He was also Chairman of the Anti-tram fare increase campaign and significantly he was a marshal in the ANC's Defiance Campaign of 1951 (Vundla 1973: 30 and 34). As a result of P.Q.'s involvement at a leadership level in ANC campaigns, Kathleen records that he was elected in 1952 onto the National Executive of the African National Congress, under the leadership of Chief Albert Luthuli. At that stage the ANC was committed to struggle for racial equality along constitutional lines, through protests, deputations and resolutions. A year earlier, however, P.Q. had been a field-marshal during the Civil Rights Disobedience Campaign. The failure of this non-violent protest led the ANC to consider more violent forms of protest. P.Q. left the National Executive after only one year due to its increasing militancy. He opposed the use of intimidation by the ANC Youth League and the ANC Women's League during the bus and schools boycotts in the mid-1950s (Lodge 1990: 121). His opposition to these boycotts led to his dismissal from the ANC (Vundla 1973:32-34). Kathleen cites two political forces that contributed to the formation of P.Q.'s political identity, namely the radicalism of youth politics and the liberalism of his parents, manifested in the 1940s and 1950s. At this point in her biography she permits a rare instance of revelation into P.Q.'s political intentions. Here we may recall Arfuch's observation that biographers with intimate knowledge of their subjects have to make decisions about what to reveal of private intentions. Kathleen's elects, at this point in her biography, to provide the reader with an insight into P.Q.'s long-term plans. She suggests 
that P.Q. foresaw the consequences of the ANC's radicalisation and militarysation. The banning of the ANC and the PAC, together with the African Indian Congress in 1960, led to some leaders being arrested, others going into exile, and a vacuum in black political leadership. Kathleen indicates that P.Q.'s decision not to follow the radical route of black politics was strategic. He aimed to step into the political vacuum 'with others who had come to believe that there was an answer to this problem' (1973: 34). Here she refers to P.Q.'s association with the MRA movement. It is at this point in P.Q.'s life that Nico Ferreira becomes influential.

\section{The Roots of Relationally-based Ethics in Nico Ferreira's Narrative}

Nico's childhood in the context of the family's memory of the death of his grandmother in the British concentration camps during the Boer War developed in him a concern for the suffering of Afrikaners. But later this concern extended to all dispossessed peoples in South Africa. Loël recounts that Nico attended Grey College, a prestigious school in Bloemfontein. After matriculating he studied at Pretoria University, graduating with a BA (Hons) in Political Science and Political Administration in 1952. As a student he was head of the Nationalist Party Jeugbond (Youth League). After graduation, he found employment in the Department of Native Affairs in 1953 (Ferreira 2006: 3 ). Along with the culturally-entrenched memory of his grandmother's death in the British concentration camps, Nico is portrayed as having a conventional Afrikaans youth, with deep-rooted schooling in the emerging Afrikaner nationalism. Loël offers no interpretation of Nico's childhood immersed in the predominant Afrikaner myth of racial superiority, but his choice of studies is informative. Attending Pretoria University and studying Political Science in the early 1950s would have put Nico in contact with debates around the formation of the Nationalist Party's formulation of their Apartheid strategy. At the time the Party was divided between Cape Afrikaners centred in Stellenbosch, and northern Afrikaners centred in Pretoria. Cape Afrikaners were in the ascendancy, headed by the Prime Minister of the time (D.F. Malan) (Koorts 2014: 379). The Pretoria-based Afrikaners were headed by H.F. Verwoerd, editor of the Afrikaans newspaper, Die Transvaler. After the Nationalist Party won the whites-only election of 1948, Verwoerd became 
minister of Native Affairs in 1950. The debate in the National Party during that period was whether Apartheid should develop cheap black labour reserves within South Africa, based on the Group Areas Act, which would enable the development of black townships outside white business areas, or should pursue separate development, which would create black independent homelands along ethnic lines. This would foster ethnic separation and service white capital in South Africa with migrant labour from the homelands. Initially the separate development idea had been formulated at Stellenbosch University in the Cape Province by the Tomlinson Commission and the Policy unit (SARBRA). The Northern Afrikaners under Verwoerd initially rejected the Tomlinson Commission, but later adopted its recommendation as the Department of Native Affairs' plan for Apartheid. These debates were central topics at the Afrikaans-medium Pretoria University campus during Nico's time as a student (Giliomee 2003: 483; and Giliomee 2016: 26). When Nico started working at the Department of Native Affairs he entered the arena where the laws dictating Apartheid legislation were being passed, significantly, the Group Areas Act of 1950 and The Prohibition of Mixed Marriages Act of 1949.

\section{What Inspired their Friendship? Development of Other- based Ethics}

Given the contrasting political and cultural backgrounds of Nico and P.Q. they should not have been able to find common purchase on which to found a friendship. P.Q. made statements such as 'the only good white is a dead white' in his youth, which reveal an early hardening antipathy towards whites (Vundla 1973: 16). Nico, by contrast, made choices in his youth which supported the Nationalist Party ideology of Afrikaner supremacy and apartheid when he led the Afrikaner Jeugbond at University. It is therefore my contention that the biographical autobiography needs to explain the sudden changes in two men's life trajectories. When these lives are considered by reading intersecting biographies, a complex and integrated reading emerges. When considering biographical autobiography, and specifically the relationship between two biographical autobiographies such as those of Kathleen Vundla and Loël Ferreira, a unique form of intertextual integrative complexity develops. The biographical accounts of the two men's lives portray them as undergoing sudden changes in their views towards forgiveness and recognition of others' 


\section{Garth Mason}

dignity. Yet, as readers, we are left pondering the deeper, unconscious causes for the spiritual turn in their lives. Neither biography reveals the inner thoughts of its subject. We can only speculate about the effect of opening the self to others' suffering, in P.Q.'s case the broad suffering of poor dispossessed blacks in South Africa, and in Nico's case stories of Boer suffering during the South African War. These encounters with empathy may have enabled them to universalise their awareness of suffering across racial lines. Levinas's insights into the presence of death for Holocaust victims is helpful in this respect because he describes the suffering of defenceless people at the hands of a brutal oppressor. He explains:

The first obvious thing in the other's face is the directness of exposure to that defencelessness. The human being in his face is the most naked; nakedness itself. But at the same time, his face faces. ... The face looks at me, calls out to me. It claims me. What does it ask for? Not to leave it alone. An answer: Here I am, my presence, of no avail perhaps, but a gratuitous movement of presence and responsibility for the other (1999: 162).

Levinas's reflections on the roots of ethics arising with confrontation of the face of the other, in particular, the naked vulnerability of the face, are very useful in of reading the biographical autobiographies of Vundla and Ferreira. There are references in both biographies that indicate that Nico and P.Q. were deeply influenced by the suffering of others and that their involvement with the MRA movement had elevated this concern for others' suffering into a spiritual principle (Foot 1935: 191; and Howard 1962: 55).

In reading the two texts in tandem, the complexity of the two men's personalities is revealed. They each possessed the capacity for openness to acknowledge the other in the immediacy of the face-to-face encounter as Levinas argues, even if their wives chose not to reveal much of their husbands' inner thoughts. The auto/biographical narratives of both P.Q. and Nico provide clear representations of the two men and the accounts of their friendship, based on shared MRA beliefs and values, provides the reader with the enactment of their inner thoughts.

I posit that both men desired a spiritual 'inner space' from which to launch new political paths. In their shared spiritual home in the MRA 
movement, they shared an imaginative space and vision for South African society. Their lives can be seen as externalising this imagined inner space in their life's work. The reader is, however, left to infer the nuances of the two men's spiritual intentions that drove their community development work. It is in this intertextual space that integrative complexity surfaces, shedding light on the constituents that enabled their friendship and their sophisticated community engagement processes. In this level of integrative complexity, both P.Q. and Nico perceived their external environments as imagined spiritual and emotional environments imbued with values, relations and beliefs. These imagined environments allowed them to develop a sense of belonging to human communities beyond political, class and race boundaries reinforced by beliefs, values and spirituality.

\section{MRA Background: The Spiritual Basis for Other-based Ethics}

While working at the Native Affairs Department, Nico Ferreira became involved in the Moral Re-armament Movement. The Moral Re-armament Movement (MRA) was established by Frank Buchman between 1915 and1921 (Boobbyer 2013: 1). Boobbyer writes:

The movement had two branches, in the USA and in Oxford, England. It was named 'The Oxford Group' (OG) in South Africa by a train porter, for want of a name to call the visiting group, but until 1929 the group did not have an official name (2013: 148).

Buchman's core tenets were quietism (guided by the Holy Spirit) and group spiritual dialogue. Bachman heard Robert Speer, a Pentecostal preacher in Philadelphia in 1902 (Austin 1975: 61; and Boobbyer 2013: 22). He was impressed by Speer's distillation 'of Jesus' teachings into four 'absolute standards' for behaviour - honesty, unselfishness, purity, and love' and these principles guided his thought (Boobbyer 2013: 22). Buchman extracted these four principles from orthodox Christianity and made them the bedrock of his movement. According to Grensted:

You cannot belong to the Oxford Group. It has no membership, badge, rules, or definite location. It is a name of a group of people who, from every rank, profession, and trade, in many countries, have surrendered 
their lives to God and who are endeavouring to lead a spiritual quality of life under the guidance of the Holy Spirit.

The Oxford Group is not a religion; It has no hierarchy, no temples, no endowments; its workers have no salaries, no plans but God's Plan; every country is their country, every man their brother. They are Holy Crusaders in modern dress, wearing spiritual armour. Their aim is a ' $\mathrm{A}$ New World order for Christ, the King' (Grensted 1933: 3).

Although not specifically religious in structure it was Christian in its core beliefs. The MRA was Pentecostal in its approach, taking its authority from the spiritual guidance of the Holy Spirit to spread the Jesus's message throughout the world. Buchman outlined the goal of the Movement as follows,

We are in a global effort to win the world to our Lord and Saviour, Jesus Christ. There is our ideology. It is the whole message of the Gospel of our Lord and Saviour, Jesus Christ. The message in its entirety is the only hope that will save the world (Mowat 1955: xi).

Buchman's aim was to make the Christian Gospel relevant to the modern world which had unified in terms global communications which made global politics and economics inextricably interconnected. He believed, consequently, that the world required a concomitant global moral and spiritual force. In addition, due to the immense increase in military capability leading totalitarian states and atomic capabilities, the world required a simultaneous moral re-armament (Mowat 1955: ix). According to Buchman, the world required the Gospel message stripped of 'traditional Christian expression' that would transcend the 'bitterness of class war and racial antagonism' (Mowat 1955: x).

The MRA had a vast global reach. The Movement sent emissaries to Europe (including Denmark, Sweden, Germany, England, Norway, Switzerland, France), India, Japan, South Africa, the then South West Africa (Namibia), the then Rhodesia (Zimbabwe), Nigeria, Gold Coast, Kenya, Egypt, New Zealand, Australia, the Middle East and the Americas. The MRA workers invited groups of people comprising labour, civil society, political leaders and professionals.

All workers in the Movement followed the practice of sitting quietly once a day and listening for guidance from the Holy Spirit, with a pen and 
paper beside them. Buchman believed that the Holy Spirit was leading the Movement to achieve international understanding between countries and communities (Leon 1940: 100 and Boobbyer 2013: 14-34). Sharing in groups was the movements social practice. It involved confession and witnessing (Henson 1933: 4). Participants in the groups were encouraged to talk about their fears and hopes for their country and the world. Buchman believed that the Jesus's message had become stifled by theology and creed. The world required an outlet for emotions (Marcel 1960: 8; and 54). The participation in the sharing groups with the accompanying generation of emotions recalls Durkheim;s observation that participation in religious rituals led to a feeling of 'collective effervescence' binding people in their shared emotions (Watson 2014: 220; and Durkheim 1976: 121).

The Oxford Group first visited South Africa in 1929 and sharing in groups was central to its strategy. The initial visits aimed at building trust between English- and Afrikaans-speakers, by holding 'house parties' where influential people from different sectors of society (education, civil society, business and legal professions) were invited. Later visits addressed the racial tension between black and white communities by inviting white community leaders along with radical black nationalists. Among the black leaders invited were Dr William Nkomo, one of the founders of the ANC Youth League, and P.Q. (Ferreira 2006: 15; and Vundla 1973: 46).

\section{The Spiritual Turn}

Loël writes that Nico became an MRA member in 1953 after attending an MRA conference in Lusaka and hearing William Nkomo talk about personal transformation as a prerequisite for political and racial transformation (Ferreira 2006: 15; Vundla 1973: 38). Both biographies confirm that the MRAinfluenced thinking of Dr. William Nkomo profoundly influenced Nico: 'Any idea that excludes anyone else is too small for the age in which we live' (Vundla 1973: 38). In 1954 Dr. William Nkomo spoke at an inter-racial assembly in Johannesburg, hosted by the MRA. Nico Ferreira was in attendance. In attendance were also leaders from across the racial and political spectrum, including ex-ANC leaders, Broederbond members, Afrikaans academics from Pretoria University and members of the Transvaal government. The purpose of the meeting was 'to plan for the moral re-armament of 


\section{Garth Mason}

every race, and the destiny of Africa as a continent under the guidance of God' (Mowat 1955: 86).

The practice of group sharing was pivotal for both Ferreira and Nkomo in their shift towards MRA influenced Christianity. William Nkomo describes his experience of the Lusaka conference.

I found something entirely unexpected (in Lusaka). I heard black men and white men testifying to their change. I was moved and decided to change, ... I realised that my Christianity was based on false premises. I had been divisive, and had never experienced the full significance of the Cross Christ. ... I have found that in bringing men to the Cross Moral Re-armament answers man's needs. ... it brings true unity because it is based on absolute moral standards (Mowat 1955: 94).

The group sharing practice had a powerful psychological and spiritual effect on participants and was catalyst for conversion experiences. Loël's account of Nico's inner thoughts on listening to Nkomo creates a dramatic contrast to Nico's traditional Afrikaner childhood, embracing Afrikaner nationalism and the politics of the Nationalist Party. Given this background, there is no indication that his life was to take a spiritual and political turn.

Nkomo's statement reveals a striking sense of integrative ipse-identity in Paul Ricoeur's sense. Ricoeur writes that 'ipse-identity involves a dialectic complementarity to that of selfhood and sameness, namely the dialectic of self and the other than self' (Ricoeur 1994: 3). According to Ricoeur ipse-identity is the dynamic quality of subjective consciousness which embraces objective relations within its subjectivity. The 'spiritual turn' as described by Nkomo and Ferreira at the MRA Lusaka conference appears to have initiated a heightened awareness of ipse-identity. But more important than Ricoeur's understanding of ipse-identity when Nico meets P.Q. is the element of the ethical which Levinas brings to the understanding of ipse-identity. For Levinas the subject enters a non-intentional relation with the objective or the other. By this Levinas means a lived ethics, according to which the subject only acts once the well-being of the other is ensured (Levinas 1999: 29). As Levinas explains:

Significance in the ethics of a past, irreducible to my present, and thus, of an immemorial past, based on the responsibility for the other man. My non-intentional participation in the history of humanity, in the past of others, who are my business (Levinas 1999: 32). 
In terms of Levinas's ethics based on recognition of the rights of the other prior to one's own rights, significantly Kathleen's biography offers the reader more insight into Nico's inner thoughts than Loël's. P.Q.'s recognition of Nico's spiritual transformation is a life-changing moment for the trade unionist as was Nico's recognition of the significance of Nkomo's words, and therefore it was crucial for P.Q. to understand Nico's thoughts. Nico explained to P.Q.: 'Something has happened in my life and I see a new hope for our country. I believe that if people like you and me decide to listen to God and do what he tells us is right, we can work together and build a real future for this part of the world' (Vundla 1973: 28). After Nico's visit to P.Q.'s home, where Nico described his experience of listening to William Nkomo talk in Lusaka, P.Q. declared, 'If an Afrikaner like this could change was anything impossible?' Nico decided to apply the spiritual philosophy of MRA in his life and his work based on these inspiring words from Nkomo. In my view, Nico's reaching out to P.Q., in Levinas's terms, to face the political other as an Other, devoid of characterization or political ties, inspired P.Q. to come to his 'road to Damascus' moment.

\section{Sophiatown - The Turning Point}

Both biographers record the significant meeting between the two men on the eve of the government's removal of Sophiatown residents. In 1954 Loël explains that Nico was assigned at the Department of Native Affairs to facilitate the removal of blacks from Sophiatown to Meadowlands. Nico describes his arrival at the offices of Native Affairs in Johannesburg:

I arrived in Johannesburg and was ushered into the office of $\mathrm{Mr}$ Engelbrecht. My first question was, 'what do the residents think of Sophiatown say?' Mr Engelbrecht looked perplexed, 'that is irrelevant', he said. 'The government has decided and this is what is going to happen' (Ferreira 2006: 16).

Nico decided to meet the Sophiatown leaders, placing him in direct conflict with the goals of the government. He met with black community leaders in the days before the removals. Nico met P.Q., initiating their friendship and a shift in P.Q.'s thinking away from antagonistic to diplomatic methods of inclusive 


\section{Garth Mason}

community politics. Through Nico P.Q. was introduced to MRA philosophy and religious thought. On the eve of the removal, Nico visited P.Q., acting as a member of the Council's removal committee. The young Nationalist Afrikaner, who worked for the Native Affairs Department (1973: 36) and was temporarily working for the Sophiatown Resettlement Board, spoke to P.Q. about the need for a new transformative approach to South Africa's political crisis that involved whites and blacks overcoming their prejudices and meeting each other on equal terms of trust (Vundla 1973: 36; Ferreira 2006: 18). Clearly Nico was initiating a dialogue outside of the directive from the Native Affairs Department. His intention was to dialogue with black leaders. He had also spoken to Dr Xuma, the ex-president of the ANC, in his home in Sophiatown the previous evening. Unsurprisingly Ferreira's meetings with Sophiatown community leaders aroused the ire of the Head of the Resettlement Board, resulting in his being sent back the Native Affairs Department in Pretoria (Ferreira 2006: 16).

The meeting between Nico and P.Q. took place against the grain of history. Indeed, the police tried to discourage Nico from visiting P.Q., warning him that P.Q. was very dangerous (Vundla 1973: 38). Nevertheless, Nico assured P.Q. that he thought it was the correct thing to do to visit him and other community leaders.

At their first meeting P.Q.'s reaction was dismissive: 'I do not talk to young people, you are far too small to come to visit me. I would like the Prime Minister to come and see me ... I want my people liberated from white supremacy and nothing will do that except a blood bath' (Vundla 1973: 38). Loël confirms Kathleen's account of the two men's first meeting (Ferreira 2006: 18). But in fact, Kathleen offers a subtext to the meeting. In contrast to P.Q.'s aggressive reaction to Nico, Kathleen affirms that in fact 'Philip had been much taken at the courtesy of this young man, and was prepared. He was ready for the first time the young man opened his mouth about the removals' (1973: 38). But instead, Kathleen explains, Nico uttered an intimate revelation: 'something has happened in my life. For myself I have decided to give up my old ways of thinking and start living differently so that a man like you can begin to trust me'. After talking to Nico and listening to his ideas for the future of South Africa, P.Q. announced,

... he was the kind of man who would always be welcome in my home. No white man at that time would come to my house, except the police 
who came to search for documents. Until Nico came I did not want to have white friends and did not think they wanted my friendship either (1973: 39).

According to Kathleen, these insights are confirmed by Loël (2006: 20). But it is very probable that Loël is merely reflecting Kathleen's capturing of P.Q.'s thoughts in this instance. The heartless move of the Nationalist government as a consequence led to further deepening the resistance against Apartheid by the ANC and other resistance movements. So, while the government's destruction and removal of people to Meadowlands from Sophiatown did transpire the next day, P.Q.'s friendship with Nico began.

Within the ANC P.Q. was experiencing criticism for his opposition to the party's increasing militarism. His continued membership of the Advisory Council in the Native Western Areas region led to increased antagonism, particularly from the ANC Youth League. P.Q. believed that his life and the safety of his family was under threat and employed bodyguards to protect his home. His conflict with the ANC climaxed in a community meeting in 1955 during the schools' boycott. According to Kathleen, the ANC had sent trucks carrying members of the ANC Youth League and the ANC Women's League to disrupt the meeting and ensure that a community vote did not take place. P.Q. asked the ANC members who were not from the area to wait outside while the voting took place. After the vote to return to schools, the ANC Youth League attacked the delegates as they left the hall. P.Q. was attacked and stabbed in the head by ANC Youth League members. He was badly injured and was taken to hospital (Vundla 1973: 41).

Nico visited him in hospital, bearing a gift of grapes, which, according to Kathleen, meant a great deal to P.Q. because it suggested the beginnings of a genuine friendship between them and challenged P.Q.'s previous racist belief that he could not befriend a white person. After P.Q.'s release from hospital Nico invited P.Q. to speak at one of the MRA house party meetings in Johannesburg (Vundla 1973: 38). P.Q. returned from the house party a completely transformed man. Kathleen describes P.Q.'s perception of that house party. The white people at the party explained:

We are not happy about things in the country. We feel change is needed. But how do we get it moving? The Africans are bitter against whites. We understand that. The whites are scared of the Africans and 
don't want to give way. So nothing happens. But suppose each person began with himself, because none of us is perfect. As far as we are concerned we are going to start changing ourselves and not wait for anyone else to begin (Vundla 1973: 44).

Kathleen relates how P.Q. lost all aggression towards the family and began prioritizing them. Then they observed him sitting quietly every day, waiting for spiritual guidance with a pen and paper beside him (Vundla 1973: 39). According to Kathleen, P.Q. followed MRA spiritual practices and values for the rest of his life. Kathleen and P.Q. visited MRA groups and conventions in Europe and the USA on numerous occasions (Vundla 1973: 38). P.Q. and Nico Ferreira spoke on MRA values in Europe and the USA over the next 14 years, including such significant platforms as NATO (Ferreira 2006: 24). P.Q. spoke in parliament in 1961 on dialogue between black and white political leaders and the Vundla house in Dube became the base for Loël and Nico to meet black leaders in Soweto (Ferreira 2006: 18).

My study of the two auto/biographies reveals the uniqueness of P.Q. and Nico's deep friendship, which transcended their cultural memories; and yet, paradoxically, their backgrounds remained determining factors in the course of their lives. Nico and P.Q.'s friendship remained intact until P.Q.'s death in 1972. Yet both Nico and P.Q.'s identities were formed within the contingencies of history. Their political and religious internal movements were shaped by their involvement with the MRA movement. In analysing their friendship, one can see their shared MRA influence guiding them to externalise their spirituality in community work. Yet it was the attenuated aspects of their cultural and political contexts that led each man to leaning more on his childhood influences. In P.Q.'s case his community-based politics in combination with his liberal politics of negotiation led to estrangement from the ANC. His opposition to the armed struggle led to his expulsion in 1954. Nico's Afrikaner identity, which he held to throughout his life, still being a member of the N.G. Kerk to the present day, informed his understanding of community development. Nico continued to follow the basic ideas of the Tomlinson Commission throughout a lifetime - the developing Black communities and economics. During the Apartheid years he worked within the homeland structures, being head of development in both the Ciskei and KaNgwane Bantustans. He worked with Apartheid-friendly investors such as Israel, Taiwan, Hong Kong and Japan from 1980-1994 to assist in the 
development of these regions (Ferreira 2006: 93). Yet I have argued in this article that both P.Q. and Nico acted from an ethics founded on the 'spiritualised' other in their community work informed by MRA spiritual philosophy. The recognition of the needs of the other resonates with Levinas's spiritual-political ethical thought. Levinas's major influence is Martin Buber. Levinas refers to Buber's conception of socialist utopianism. The failure of Socialism as a state policy initiated the socialism of civil society founded on seeing the other as 'thou' (Levinas 1999: 112; and Buber 1971). For Buber, according to Levinas, socialism needed to be rooted in the relations 'in the common life of man' (1999: 113).

P.Q. continued to work for the MRA until he died, while Nico left the MRA in the 1970s. P.Q.'s children have maintained the long friendship with the Ferreira family (Ferreira family archive). The focus of P.Q.'s later work was on education, in line with his liberal leanings of social development through education. Nico's later work remained in grassroots development. Perhaps his greatest achievement was as mayor of the small Eastern Cape town of Stutterheim where he worked with the local ANC structures in alliance with the white community to bring economic development to the small Eastern Cape region in the late 1980s and early 1990s (Ferreira family archives and Ferreira 2006: 148).

\section{Conclusion}

This close reading of the biographies of Nchibadi Betty Kathleen Mashaba (Kathleen Vundla) - P.Q.: The story of Philip Vundla of South Africa (1973) and Loël Ferreira's text, In case anyone asks (2006) about their respective husbands, P.Q. Vundla and Nico Ferreira, highlights the deep friendship between the two men. What is significant in excavating the two men's lives by reading their wives biographies is that, paradoxically, when they transcended their cultural narratives via a linking spiritual narrative in the form of the MRA movement they were able to meet each other even though their respective cultural heritage was so formative in both their lives. As Levinas would have it, in their meeting face-to-face devoid of social historical impressions, just one face facing another with a desire to transcend the boundaries that separate them and ensuring the human and spiritual dignity of the other is recognised. Despite the cultural baggage that comprises their identity a higher principle, driven by 
the MRA, fostered and enabled their connection and friendship, encompassing trust and care. They could recognise their shared humanity. But what enabled both men to transcend the political ideological strictures of their identity to enable their meeting? From the biographies it appears that both men were inspired by statements that shifted their perspective from individual and sectarian thought to universal categories of human care via what has been termed in this article, 'the spiritual turn' enabling the development of relationality between self and other. Again, this resonates with Levinas's notions of totality and alterity and transcendence. But significantly for this study, the constituents that enabled the formation of the friendship are revealed through a combination of micro and macro history that a study of biography allows. The biographical stories of both Kathleen Vundla and Loël Ferreira, when read together, offer a combined narrative that adds texture and nuance the history of Apartheid on the Witwatersrand. The significance of this study of P.Q Vundla and Nico Ferreira, by reading their biographies together, is that it places the importance of factors such as friendship based on spirituality and shared religious belief on the large canvass of South African history.

\section{References}

Austin, H.W. 1975. Frank Buchman as I Knew Him. London: Grosvenor Books.

Barbour, J.D. 2004. The Value of Solitude: The Ethics and Spirituality of Aloneness in Autobiography. Charlottesville: University of Virginia Press.

Boobbyer, P. 2013. The Spiritual Vision of Frank Buchman. University Park, Pennsylvania: The Pennsylvania State University Press.

Buber, M. 1971. I and Thou. New York: Simon \& Schuster.

Caine, B. 2010. Bibliography and History. Basingstoke: Palgrave Macmillan. Chansky, R.A. \& E. Hipchen (eds.) 2016. The Routledge Auto/biography Studies Reader. London: Routledge.

Durkhein, E. 1976. The Elementary Forms of the Religious Life. London: Allen \& Unwin Ltd.

Ferreira, L. 2006. In Case Anyone Asks. Copyright Ferreira, L. 2006.

Foot, S. 1935. Life began Yesterday. Kingswood: William Heinmann Ltd. 
P.Q. Vundla and Nico Ferreira - A Uniquely Religiously-based Friendship

Giliomee, H. 2003. The Afrikaners: Biography of a People. Cape Town: Tafelberg.

Giliomee, H. 2016. Historian: An Autobiography. Cape Town: Tafelberg. Henson, H.H. 1933. The Group Movement: Being the First Part of the Charge Delivered at the Third Quadrennial Visitation of his Diocese together with an Introduction. Humphrey Milfor: Oxford University Press.

Howard, P. 1962. Frank Buchman's Secret. London: Heinemann.

J.B. Marks (obituary) 1972. SACP. Available at: http://www.sacp.org.za/ main.php?ID=2304. (Accessed on 02 June 2017.)

Koorts, L. 2014. D.F. Malan and the Rise of Afrikaner Nationalism. Cape Town: Tafelberg.

Leon, P. 1940. The Philosophy of Courage or the Oxford Group Way. London: George Allen \& Unwin.

Levinas, E. 1969. Totality and Infinity: An Essay on Exteriority. Lingis, A. (trans.). Pittsburgh: Duquesne University Press.

Levinas, E. 1999. Alterity and Transcendence. New York: Columbia University Press.

Lodge, T. 1990. Black Politics in South Africa since 1945. Johannesburg: Ravan Press.

Luz Fuentes-Vàsquez, C. 2013. Dangerous Writing: The Autobiographies of Willa Muir, Margaret Laurence and Janet Frame. Amsterdam: Rodopi B.V.

Grensted, L.W.1933. What is the Oxford Group? London. Oxford University Press.

Marcel, G. 1960. Fresh Hope for the World: Moral Re-armament in Action. Gateshead on Tyne: Northumberland Press Ltd.

Mowat, R.C. (ed.) 1955. Report on Moral Re-armament. London: Blandford Press.

Peperzak, A. 1993. To the Other: An Introduction to the Philosophy of Emmanuel Levinas. West Lafayette: Perdue University Press.

Pinker, S. 2012. The Better Angels of Our Nature: A History of Violence and Humanity. London: Penguin Books.

Ricoeur, P. 1994. Oneself as Another. Blamey, K. (trans.). Chicago: The Chicago University Press.

Spoerri, T. 1976: Dynamic of Silence: Frank Buchman's Relevance Today. London: Grosvenor Books.

Vundla, K. 1973. P.Q.: The Story of Philip Vundla of South Africa. Lans- 
Garth Mason

downe: Citadel Press.

Watson, P. 2014. The Age of Nothing: How We have Sought to Live since the Death of God. London: W\&N Ltd.

\section{Archives}

Ferreira, L. n.d. Ferreira Family Archives. Hermanus.

Garth Mason Department of Religious Studies, and Arabic University of South Africa masongj@unisa.ac.za 